Original Research Paper

\title{
Uji Efektivitas Ekstrak Buah Kesemek (Dyospiros Kaki L.) Sebagai Antibakteri Terhadap Bakteri Escherichia Coli
}

\author{
Therry Prosperita K. Wau ${ }^{1 *}$, Diaz F. Izdihar², Katherine Gunawan ${ }^{3}$, Yolanda Eliza Putri Lubis ${ }^{4}$ \\ 1,2,3,4 Fakultas Kedokteran Umum, Universitas Prima Indonesia, Medan, Indonesia;
}

\section{Riwayat artikel}

Received : 21 Februari 2019

Revised : 22 Mei 2019

Accepted : 8 Juli 2019

Published : 4 November 2019

*Corresponding Author:

Therry P.K Wau,

Fakultas Kedokteran Umum, Universitas Prima Indonesia, Medan, Indonesia;

Email: therrywau@gmail.com

\begin{abstract}
Abstrak : Kesemek (Dyospyros kaki L.) merupakan buah yang berada di tanaman dataran tinggi (pegunungan). Dapat tumbuh dimana saja pada suhu rendah, kelembapan tinggi, intensitas matahari tidak 100\% (teduh/mendung). Buah ini mempunyai kandungan senyawa yang memiliki potensi antimikroba yang menghambat pertumbuhan bakteri Escherichia coli. Penelitian ini bertujuan untuk mengetahui adanya efektifitas ekstrak kesemek terhadap pertumbuhan bakteri Escherichia coli pada konsentrasi 100\%, 90\%, 80\%, 70\%, $60 \%$, dan $50 \%$. Penelitian ini merupakan penelitian eksperimental laboratotium dengan metode difusi cakram.. Parameter yang diukur adalah besarnya zona hambat minimum dan zona hambat optimum ekstrak terhadap bakteri. Hasil penelitian didapatkan ekstrak buah kesemek memiliki efektivitas antibakteri pada Escherichia coli, dimanazona hambat minimum rata-ratanya pada konsentrasi $70 \%(6,1 \mathrm{~mm})$ dan zona hambat optimum rata-rata pada konsentrasi $100 \%(8,8 \mathrm{~mm})$. Semakin tinggi konsentrasi ekstrak yang diberi maka semakin besar daya antibakterinya. Hasil ini menunjukan bahwa ekstrak buah kesemek memiliki efektivitas antibakteri yang lemah terhadap pertumbuhan bakteri Escherichia coli sesuai klasifikasi respon zona hambat bakteri.
\end{abstract}

Keywords: Kesemek (Dyospyros kaki L.), antibakteri, Escherichia coli

Abstract : Persimmon (Dyospyros kaki L.) is a fruit that is in highland (mountain) plants. Can grow anywhere at low temperatures, high humidity, the intensity of the sun is not $100 \%$ (shade / cloudy). This fruit contains compounds that have antimicrobial potential which inhibits the growth of Escherichia coli bacteria. This study aims to determine the effectiveness of persimmon extract on the growth of Escherichia coli bacteria at concentrations of $100 \%, 90 \%$, $80 \%, 70 \%, 60 \%$, and $50 \%$. This study was an experimental laboratory with disc diffusion method. The parameters measured were the size of the minimum inhibition zone and the optimum zone of extract inhibition against bacteria. The results showed persimmon fruit extracts had antibacterial effectiveness in Escherichia coli, where the minimum inhibition zone was at a concentration of $70 \%(6.1 \mathrm{~mm})$ and the optimum inhibition zone averaged at a concentration of $100 \%(8.8 \mathrm{~mm})$. The higher the concentration of extract given, the greater the antibacterial power. These results indicate that persimmon fruit extract has a weak antibacterial effectiveness against the growth of Escherichia coli bacteria according to the classification of bacterial inhibitory zone responses.

Keywords: Persimmon (Dyospyros kaki L.), antibacterial, Escherichia coli 


\section{Pendahuluan}

Tanaman buah sejak dahulu telah dikonsumsi sebagai makanan enak yang sangat mudah ditemukan dan juga dikenal memiliki berbagai kandungan yang sangat baik bagi makhluk hidup. Karena pada tanaman buah mengandung senyawa bioaktif yang dapat digunakan sebagai obat. Salah satu tanaman buah yang dapat digunakan adalah buah kesemek. Salah satu tanaman buah yang dapat digunakan adalah buah kesemek (Dyospyros kaki) yang merupakan tanaman introduksi yang berasal dari Eropa, dibawa oleh Belanda. Dapat tumbuh dimana saja pada suhu rendah, kelembapan tinggi, intensitas matahari tidak 100\% (teduh/mendung). Dan di Indonesia yang menghasilkan kesemek adalah Jawa Barat dan Jawa Timur, di mana buah ini ditanam pada daerah-daerah tinggi di pegunungan (Redaksi Health, 2012).

Pada penelitian sebelumnya dikatakan bahwa buah kesemek (Dyospyros kaki L.) memiliki kandungan berupa air, protein, lemak, karbohidrat, vitamin A, vitamin $\mathrm{C}$, kallium, postassium, phenol, dan tannin. Dari semua kandungan tersebut juga ketahui bahwa buah kesemek dapat digunakan sebagai obat pencegah kanker dan penyakit jantung, bahkan sebagai obat penurun tekanan darah tinggi (Indah Kurniasari et al., 2017).

Escherichia coli adalah salah satu bakteri gram negatif enteric (Enterobactericeace) yaitu kuman flora normal yang ditemukan dalam usus besar manusia. Bakteri ini merupakan penyebab diare dan infeksi saluran kemih (Nova Suryati, et al., 2017). Escherichia coli berbentuk batang pendek (kokobasil), negative Gram, ukuran 0,4-0,7 $\mu \mathrm{m}$ (Agus et al., 2013). Morfologi yang khas tampak pada pertumbuhan di medium solid in vitro, tetapi morfologi tampak sangat beragam dalam specimen klinis. Kapsul lebih kecil dibandingkan dengan Klebsiella dan bersifat irregular (Jawetz, Melnick, dan Adelberg, 2015). Sebagian besar galur (Strain) bakteri ini tidak berbahaya, tetapi beberapa serotype dapat menyebabkan keracunan makanan pada manusia (Soedarto, 2016).

Penyakit diare masih menjadi salah satu masalah kesehatan masyarakat yang penting, karena merupakan penyumbang utama ketiga angka kesakitan dan kematian anak di berbagai Negara termasuk Indonesia. Penyebab utama kematian akibat diare adalah dehidrasi akibat kehilangan cairan dan elektrolit melalui tinja. Jika hal itu terjadi terus-menerus akan mengakibatkan gangguan pertumbuhan anak (Widoyono, 2011).

Sekitar lima juta anak di seluruh dunia meninggal karena diare akut. Di Indonesia pada tahun 70 sampai 80an, prevalensi diare sekitar 200-400 per 1000 penduduk per tahun. Dari angka prevalensi tersebut, 70-80\% menyerang anak dibawah usia lima tahun (balita). Golongan usia ini mengalami 2-3 episode diare per tahun. Diperkirakan kematian anak akibat diare sekitar 200-250 ribu setiap tahunnya (Depkes RI, 2011). Dalam keadaan infeksi, kebutuhan sari makanan pada anak yang mengalami diare akan meningkat, sehingga setiap serangan diare akan menyebabkan kekurangan gizi. Jika hal itu terjadi terus-menerus akan mengakibatkan gangguan pertumbuhan anak (Widoyono, 2011).

Untuk itu, banyak penelitian yang dilakukan untuk mengobati hal tersebut. Pengobatan antibakteri pada umumnya dilakukan untuk kasus ini. Salah satu antibakteri yang digunakan adalah dari tumbuhantumbuhan. Tumbuhan dipercaya dapat menghambat pertumbuhan bakteri. Salah satu penelitian dari tumbuhtumbuhan yaituekstrak daun kelor (Moringa oleifera L.) yang mengandung flavonoid, fenol dan alkaloid menuliskan hasil efektifitas antibakteri terhadap Escherichia coli (Lusi L.R.H Dima, et al., 2016).

Pada penelitian Roslizawaty, et al., 2013, ekstrak rebusan sarang semut yang diuji terhadap bakteri Escherichia coli menuliskan bahwa ekstrak tersebut mengandung tannin, flavonoid dan polifenol.

Pada penelitian Maria Tuntun, 2016, ekstrak daun pepaya (Carica papaya L.) yang diuji terhadap bakteri Escherichia coli menuliskan ekstrak tersebut mengandung senyawa aktif seperti alkaloid, saponnin, tannin, dan tripenoid. Penelitian Afnidar, 2014 juga menuliskan Ekstrak metanol kalus batang W. biflora mengandung senyawa metabolit sekunder yang terdiri dari alkaloid, terpenoid dan flavonoid, sedangkan ekstrak metanol kalus daun W. biflora terdiri dari senyawa alkaloid dan terpenoid.

Berdasarkan uraian diatas dan ditemukan adanya indikasi buah kesemek yang memiliki kandungan antibakteri, maka peneliti mencoba melakukan penelitian uji efektivitas Escherichia coli pada buah kesemek.

\section{Bahan dan Metode}

\section{Bahan}

Bahan-bahan yang digunakan adalah buah kesemek, etanol, nutrient agar (NA), Nutrient Broth (NB), dan bahan-bahanyang berkualitas proanalisa (E.Merek) : $\alpha$-naftol, amil alcohol, asam nitrat pekat, asam asetat anhidrat, asam klorida pekat (HCL), asam sulfat pekat, benzene, besi (III) klorida, bismuth nitrat, etilasetat, iodium, isopropanol, kalium iodide (KI), klorofom, methanol, natrium hidroksida $(\mathrm{NaOH})$, natrium klorida (NaCl), n-heksana, raksa (II) klorida, serbuk magnesium( $\mathrm{Mg}$ ), timbal (II) asetat dan toluene, dan Bakteri E.coli. 


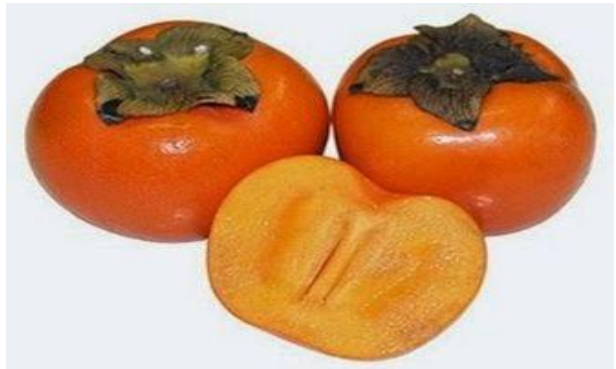

Gambar 1. Buah Kesemek

(Sumber : https://manfaatmenulisinibanyak.wordpress.com)

\section{Metode}

Buah kesemek diekstrak dengan metode maserasi dengan menggunakan pelarut etanol. Kemudian selanjutnya diuji fitokimia secara kualitatif untuk mengetahui ada atau tidaknya senyawa tannin, flavonoid, saponin, terpenoid, dan alkaloid.

\section{Pembuatan Ekstrak Buah Kesemek}

Buah kesemek (Dyospyros kaki L.) dicuci dengan air bersih terlebih dahulu lalu dikeringkan, kemudian diiris setipis mungkin. Hasil irisan diletakan pada kertas perkamen secara acak tanpa ada yang berdekatan untuk menghindari pembusukan. Kemudian dikeringkan dalam lemari pengering pada suhu $40^{\circ} \mathrm{C}$.

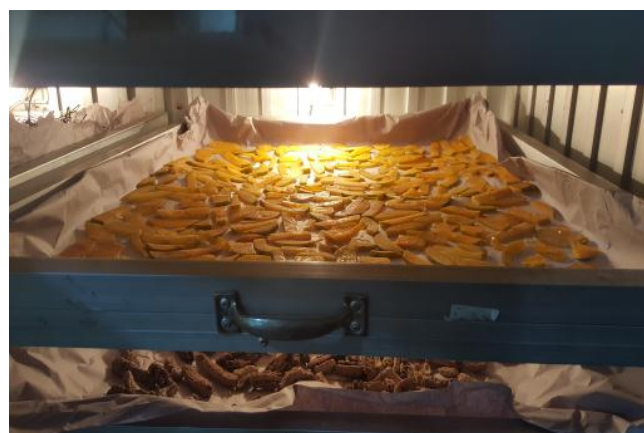

Gambar 2. Hasil potongan tipis kesemek dan proses pengeringannya

Buah kesemek yang telah kering diblender hingga menjadi serbuk. Kemudian serbuk di timbang dan dibagi dua kedalam dua jar tertutup, yang dimana satu jar berisi 3 gram serbuk kesemek. Kemudian dimaserasi menggunakan pelarut ethanol $96 \%$ sebanyak 5 liter, kemudian didiamkan selama 5 hari terlindungi dari cahaya sambil diaduk secara konstan. Hasil maserasi tersebut disaring dengan kertas saring dan dimasukan kedalam jiregen biasa. Hasil maserat digabungkan lalu diuapkan dengan alat rotary evaporator pada temperature kurang dari $40^{\circ} \mathrm{C}$ sehingga diperoleh ekstrak etanol kental kemudian dikeringkan dengan freeze dryer (Depkes RI, 1979).

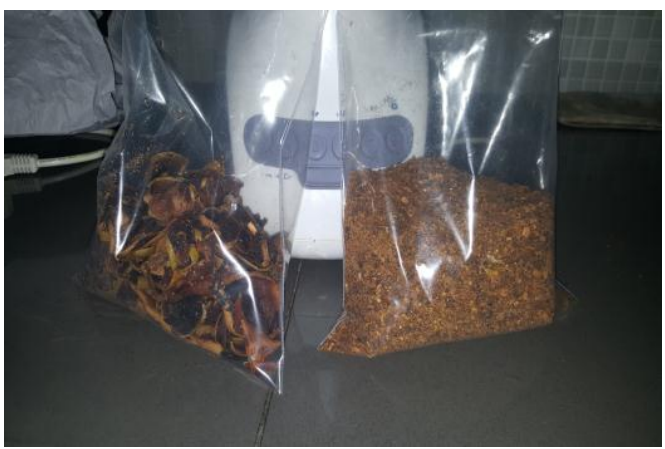

Gambar 3. Hasil buah kesemek yang telah dikeringkan dan sudah di blender

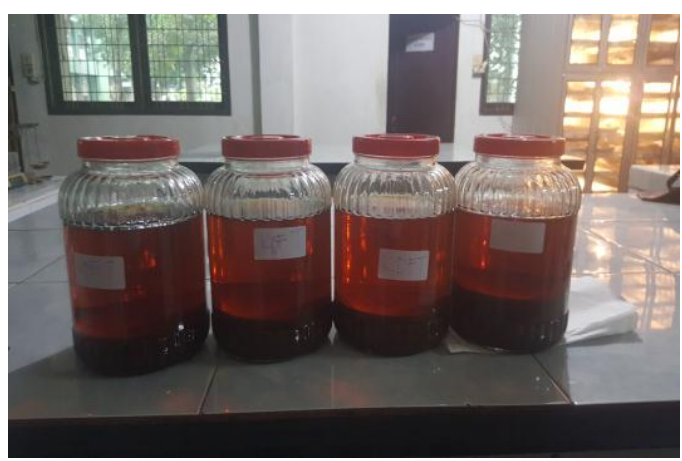

Gambar 4. Buah kesemek di larutkan dalam larutan etanol

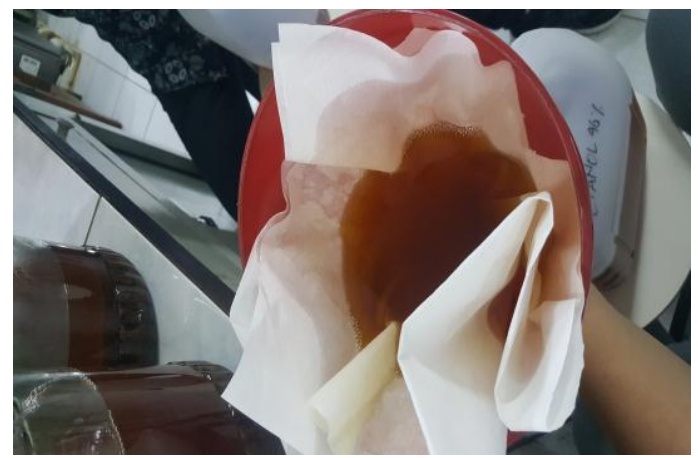

Gambar 5. Penyaringan hasil larutan etanol dan buah kesemek 


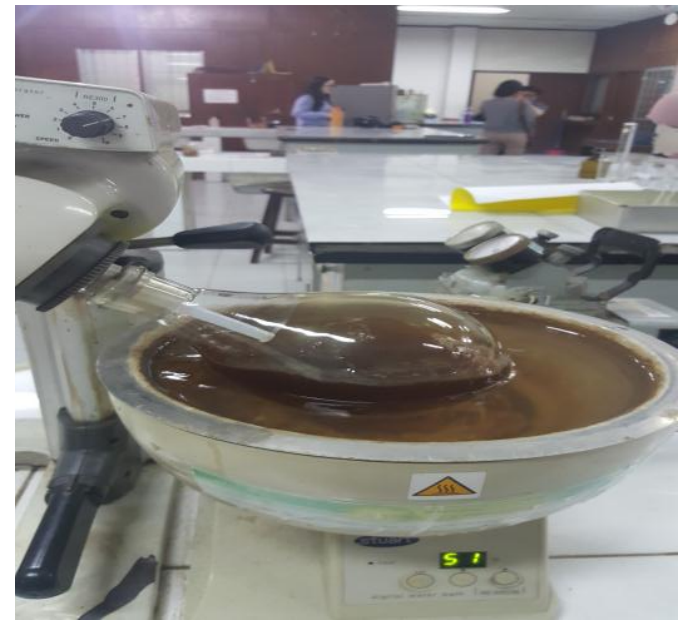

Gambar 6. Proses pemisahan etanol dan ekstrak kesemek

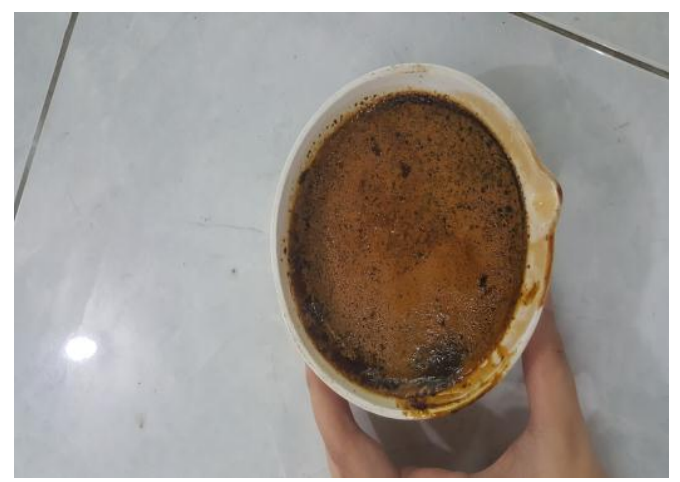

Gambar 7. Ekstrak kesemek

Skrining fitokimia dari ekstrak etanol buah kesemek meliputi pemeriksaan golongan senyawa alkaoida, flavanoida, saponin, tannin, glikosida, glikosida antrakinon dan steroida/triterpenoida (Depkes RI, 1995)

\section{Pembuatan larutan pereaksi}

1. Peraksi mayer

Dilarutkan 1,358 g merkuri (II) klorida dengan $60 \mathrm{ml}$ akuades (larutan A). dilarutkan 5 g kalium iodida dengan $10 \mathrm{ml}$ akuades (larutan B). dituangkan larutan A ke dalam larutan B, diencerkan dengan akuades sampai volume larutan menjadi $100 \mathrm{ml}$ (Depkes RI, 1979).

2. Pereaksi natrium hidroksida $2 \mathrm{~N}$

Ditimbang $\mathrm{NaOH}$ sebanyak 8,002 g, kemudian dilarutkan dalam air suling hingga $100 \mathrm{ml}$ (Depkes RI, 1979).

3. Peraksi Bouchardat

Dilarutkan kalium iodide dan $2 \mathrm{~g}$ iodium sebanyak 4 g dalam air suling secukupnya hingga $100 \mathrm{ml}$ (Depkes RI, 1995)

\section{Pereaksi Dragendorff}

Dibuat pereaksi dua larutan persediaan : (1) 0,6 g bismuth nitrat dalam $2 \mathrm{ml}$ HCL pekat dan $10 \mathrm{ml}$ air; (2) $6 \mathrm{~g}$ kalium iodida dalam $10 \mathrm{ml}$ air. Larutan persediaan ini dicampur dengan $7 \mathrm{ml}$ HCL pekat dan $15 \mathrm{ml}$ air (Depkes RI, 1979).

5. Pereaksi besi (III) klorida $1 \%$

Ditimbang besi (III) klorida sebanyak $1 \mathrm{~g}$, kemudian dilarutkan dalam air suling hingga $100 \mathrm{ml}$ lalu disaring (Depkes RI, 1979).

6. Pereaksi asam klorida $2 \mathrm{~N}$

Diambil asam klorida pekat 7,293 g kemudian ditambah air suling sampai $100 \mathrm{ml}$ (Depkes RI, 1979).

7. Pereaksi timbal (II) asetat $0,4 \mathrm{M}$

Ditimbang timbal asetat sebanyak 15,17 g, kemudian dilarutkan dalam air suling bebas karbondioksida hingga $100 \mathrm{ml}$ (Depkes RI, 1979).

8. Pereaksi Liebermann-Bourchard

Campurkan 5 bagian volume asam sulfat $\mathrm{P}$ dengan 50 bagian volume etanol $95 \%$ P. Tambahkan hatihati 5 bagian volume asetat anhidrida ke dalam campuran tersebut, dinginkan (Depkes RI, 1995).

9. Pereaksi Molish

Dilarutkan alfa naftol sebanyak $3 \mathrm{~g}$ dalam $15 \mathrm{ml}$ etanol $95 \%$ ditambahkan dengan asam nitrat 0,5 $\mathrm{N}$ secukupnya hingga diperoleh larutan $100 \mathrm{ml}$ (Depkes RI, 1979)

\section{Hasil Skrining Fitokimia Buah Kesemek}

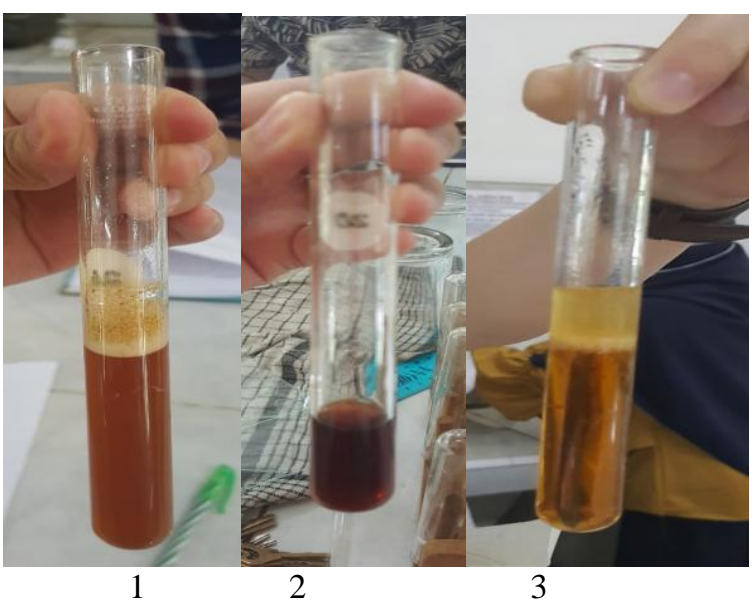

Gambar 8. Hasil Skrining Fitokimia Buah Kesemek

Keterangan :

1. hasil uji Saponin

2. hasil uji Tanin

3. hasil uji Flavanoida 


\section{Hasil Skrining Fitokimia Buah Kesemek Lanjutan}
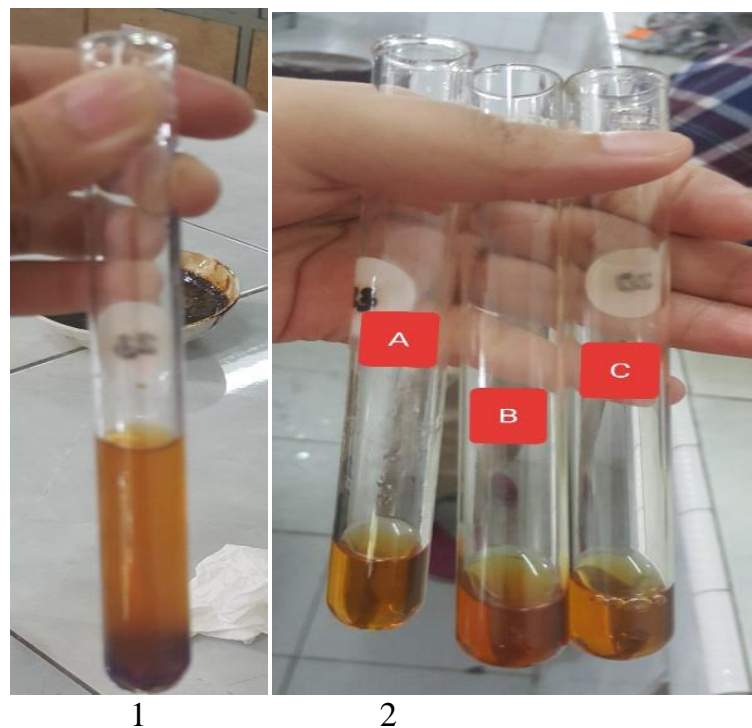

Gambar 9. Hasil Skrining Fitokimia Buah Kesemek Lanjutan

Keterangan :

1. hasil uji glikosida

2. hasil uji Alkaloid. (a) Mayer, (b) bouchard, (c) Dragendorff

Ekstrak buah kesemek tersebut diuji efektivitas antibakteri pada konsentrasi $100 \%, 90 \%, 80 \%, 70 \%, 60 \%$, dan 50\% dengan menggunakan metode disk diffusion dan pengukuran zona hambat. Dan dilakukan pengulangan sebanyak tiga kali pada masing-masing perlakuan.

\section{Hasil dan Pembahasan}

\section{Hasil}

\section{Hasil Skrining Fitokimia}

Skrining fitokimia yang dilakukan untuk menentukan senyawa metabolit sekunder yang terdapat didalam tumbuhan. Hasil skrining fitokimia terhadap ekstrak buah kesemek (Dyospyros kaki L.) menunjukan bahwa buah kesemek mengandung golongan senyawa metabolit sekunder seperti yang terlihat pada Tabel 5.1 berikut.
Tabel 1. Hasil skrining fitokimia ekstrak buah kesemek

\begin{tabular}{r|lc}
\multicolumn{1}{c}{ No. } & Parameter & Hasil \\
\hline 1 & Alkaloida & - \\
2 & Glikosida & + \\
3 & Flavanoid & + \\
4 & Tanin & + \\
5 & Saponin & + \\
6 & Triterpenoid/steroid & + \\
Keterangan : $\quad(+)=$ positif \\
\end{tabular}

Hasil pada Tabel 5.1 diatas menunjukan bahwa ekstrak buah kesemek positif mengandung senyawa aktif glikosida, flavonoid, tannin, saponin, dan triterpenoid/steroid yang dimana senyawa-senyawa tersebut memiliki potensi sebagai antibakteri. Kemudian hasil ekstrak buah kesemek tersebut digunakan pada uji antibakteri terhadap Escherichia coli.

\section{Hasil uji efektivitas ekstrak kesemek}

Hasil pengukuran diameter daerah hambatan pertumbuhan bakteri Escherichia coli dalam ekstrak etanol buah kesemek (Dyospyros kaki L.) dapat dilihat pada Tabel 2 berikut.

Tabel 2. Hasil pengukuran diameter daerah hambat pertumbuhan bakteri E.coli

\begin{tabular}{cc}
\hline $\begin{array}{c}\text { Konsentrasi } \\
\text { buah kesemek } \\
(\%)\end{array}$ & $\begin{array}{c}\mathrm{R} \\
(\mathrm{mm})\end{array}$ \\
\hline $\mathbf{1 0 0}$ & 8,8 \\
\hline $\mathbf{9 0}$ & 7,8 \\
\hline $\mathbf{8 0}$ & 7,1 \\
\hline $\mathbf{7 0}$ & 6,1 \\
\hline $\mathbf{6 0}$ & - \\
\hline $\mathbf{5 0}$ & - \\
\hline & $\mathrm{P}=$ percobaan \\
$\mathrm{R}=$ rata-rata diameter
\end{tabular}




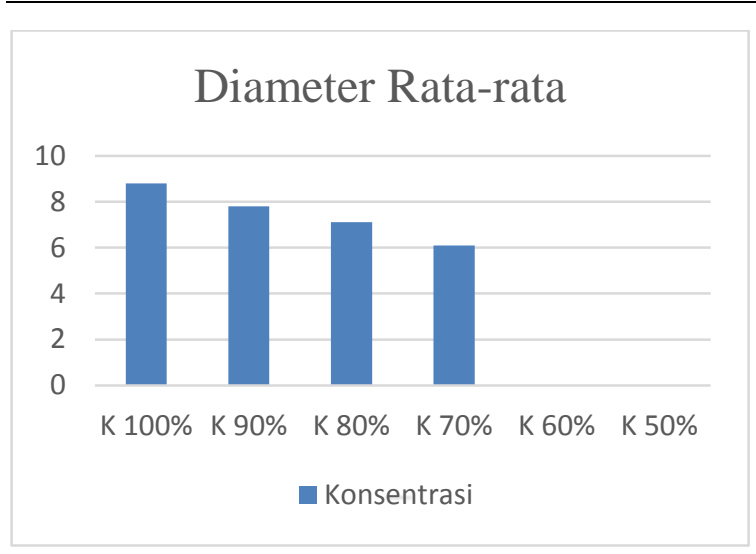

Gambar 10. Diagram batang hasil pengukuran diameter hambat pertumbuhan bakteri E.coli.

Dari Tabel 2 dan Gambar 10 dapat diketahui hasil rata-rata konsentrasi tersebut didapat Konsentrasi hambat optimum yaitu pada konsentrasi $100 \%(8,8 \mathrm{~mm})$ dan Konsentrasi Hambat Minimum (KHM) pada konsentrasi $70 \%$ (6,1 mm), yang dimana termasuk dalam klasifikasi zona hambat yang lemah.

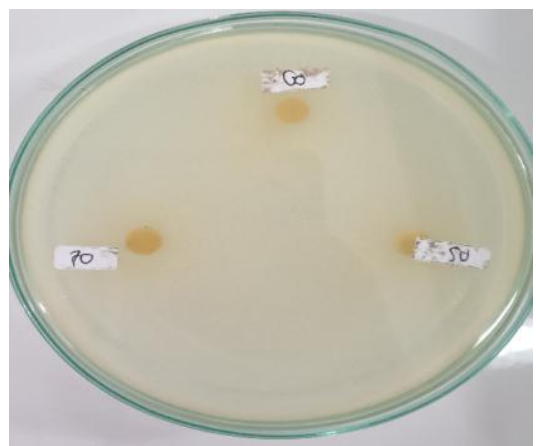

Gambar 11. Hasil uji efektivitas antibakteri Escherichia coli dalam ekstrak etanol buah kesemek pada konsentrasi $60 \%, 60 \%, 70 \%$

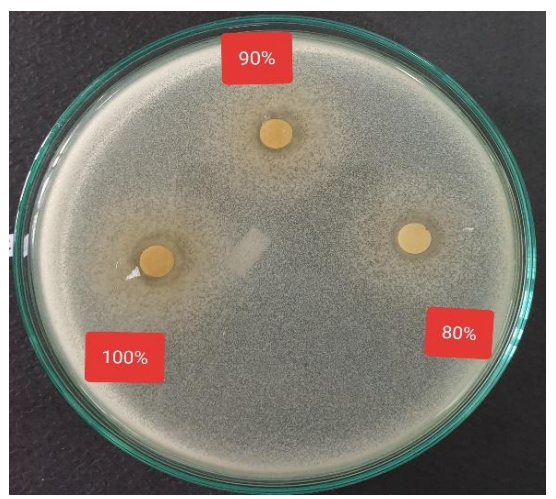

Gambar 12. Hasil uji efektivitas antibakteri Escherichia coli dalam ekstrak etanol buah kesemek pada Konsentrasi $80 \%$, 90\%, 100\%

\section{Pembahasan}

Skrining fitokimia merupakan tahap awal dari penelitian ini yang bertujuan untuk memberikan gambaran tentang golongan senyawa yang terkandung dalam buah kesemek (Dyospyros kaki L.). Berdasarkan uji fitokimia yang telah dilakukan hasilnya menunjukan bahwa ekstrak buah kesemek mengandung senyawa aktif glikosida, flavonoid, tannin, saponin, dan triterpenoid/steroid.

Tannin terdapat luas dalam tumbuhan berpembuluh, dalam angiospermae terdapat khusus dalam jaringan kayu (Harborne, 1987). Kadar tannin yang tinggi mempunyai arti pertahanan tumbuhan, mambantu mengusir hewan pemangsa tumbuhan. Beberapa senyawa turunan tannin memiliki aktivitas sebagai antimotilitas, antisekretori dan antibakteri. Senyawa tannin mempunyai sifat adstringent yang diperlukan untuk mengatasi disentri dan diare, yang sifatnya mengerutkan selaput lender usus sehingga mengurangi pengeluaran cairan diare dan disentri serta menghambat sekresi elektrolit (Tan dan Rahardja, 2007).

Flavonoid merupakan senyawa yang memiliki fungsi pengaturan tubuh, pengaturan fotosintesis, kerja antimikroba dan antivirus untuk tumbuhan (Robinson, 1995). Mekanisme kerja dari flavonoid dalam menghentikan diare yaitu dengan menghambat motilitas usus yang menyebabkan berkurangnya sekresi cairan dan elektrolit. Tripenoid merupakan golongan terpenoida yang berpotensi sebagai antimikroba. Selain itu triterpenoida memiliki sifat antijamur, insektisida, antibakteri, dan antivirus (Robinson, 1995).

Saponin dapat digunakan sebagai racun dan antimikroba (jamur, bakteri, dan virus). Saponin terdiri dari dua, yaitu sapoinin steroid dan saponin triterpenoid. Saponin memberikan hasil yang lebih baik sebagai antibakteri jika menggunakan pelarut polar seperti etanol 70\%. Pada konsentrasi rendah saponin menyebabkan hemolisis sel darah merah sehingga berfungsi sebagai antibakteri (Harborne, 1987).

Bakteri Escherichia coli merupakan bakteri negatif yang normal dalam usus manusia, namun berbahaya saat bersifat pathogen yang dimana umumnya sebagai penyebab diare. Pada beberapa penelitian Roslizawaty, et al., 2013 sebelumnya seperti ekstrak rebusan sarang semut yang diuji terhadap bakteri Escherichia coli menuliskan hasil efektivitas antibakteri yang kuat pada konsentrasi 25\% (10,3 mm) dan 50\% (11,5 $\mathrm{mm})$ yang dimana ekstrak tersebut mengandung tannin, flavonoid dan polifenol. Berdasarkan klasifikasi zona hambat ekstrak tersebut termasuk dalam zona hambat lemah yaitu berkisar 1-15 mm.

Penelitian Lusi L.R.H, 2016 ekstrak daun kelor (Moringa oleifera L.) yang mengandung flavonoid, fenol dan alkaloid menuliskan hasil efektifitas antibakteri 
terhadap Escherichia coli, yang kuat pada konsentrasi $20 \%$, yaitu $15,83 \mathrm{~mm}, 40 \%$ yaitu $19,50,80 \%$ yaitu 22,66 . Berdasarkan klasifikasi zona hambat ekstrak tersebut termasuk dalam zona hambat kuat yaitu berkisar sedang (16-10 mm) dan kuat (>20 mm).

Pada penelitian Maria Tuntun, 2016, ekstrak daun pepaya (Carica papaya L.) yang diuji terhadap bakteri Escherichia coli menuliskan hasil efektivitas antibakteri yang kuat pada konsentrasi $100 \%$ yaitu 9,1 mm. Yang dimana ekstrak daun papaya mengandung senyawa aktif seperti alkaloid, saponnin, tannin, dan tripenoid. Dan berdasarkan klasifikasi zona hambat, ekstrak daun tersebut termasuk dalam zona hambat lemah yaitu berkisar 1-15 mm.

Dari ketiga penelitian diatas dapat diketahui bahwa terdapat persamaan kandungan senyawa yang berpotensi sebagai antibakteri dalam ekstrak kesemek yang digunakan dalam penelitian ini. Dan beberapa diantaranya memiliki kandungan yang berbeda. Hal ini menandakan bahwa kandungan dalam ekstrak buah kesemek sangat mempengaruhi zona hambat pada bakteri Escherichia coli.

Berdasarkan klasifikasi respon zona hambat menurut Greenwood 2005, bila ukuran diameter zona terang $>20 \mathrm{~mm}$ maka zona hambatnya adalah kuat, hasil zona terang 16-20 $\mathrm{mm}$ adalah zona hambat sedang, sedangkan ukuran zona terang 1-15 mm adalah zona hambat lemah. Maka dari hasil penelitian diatas menunjukan bahwa ekstrak buah kesemek termasuk dalam klasifikasi zona hambat lemah. Karena hanya mampu menghambat sebesar $8,8 \mathrm{~mm}$ pada konsentrasi $100 \%$.

\section{Kesimpulan}

Berdasarkan uji efektifitas yang telah dilakukan dan menunjukan hasil ekstrak kesemek memiliki efektivitas yang sangat lemah terhadap bakteri Escherichia coli dan jika dibandingkan dengan ekstrak pada penelitian yang lain, maka pada hasil penelitian ini dapat disimpulkan bahwa kemungkinan hasil daya hambat yang lemah pada ekstrak buah kesemek dikarenakan kandungan senyawa-senyawa aktif antibakteri dalam ekstrak buah kesemek (Dyospyros kaki L.) sangat sedikit yang dapat mempengaruhi laju hambatan pertumbuhan bakteri Escherichia coli.

\section{Ucapan terima kasih}

Peneliti sangat berterimakasih umumnya kepada dosen pembimbing peneliti dr. Yolanda Lubis, M.K.M selama proses penulisan penelitian, kepada Bapak Edi Fachrial, M.si yang telah membantu peneliti dalam proses publishing jurnal ini dan kepada teman-teman yang telah ikut bagian dalam penelitian maupun penulisan ini.

\section{Daftar Pustaka}

Redaksi Health Secret (2012). Keajaiban Antioksidan Kesemek. Jakarta: Elexmedia.

Kurniasari, Indah (2017). Prediksi Kandungan Kimia Buah Kesemek (Diospyros Kaki L.) Dengan Spektroskopi Nir. Bogor: IPB;

Suryati, Nova (2017). Uji Efektivitas Ekstrak Aloe vera terhadap pertumbuhan Bakteri Escherichia coli Secara In Vitro.Jurnal kesehatan Andalas, 6(3):518-521

Soedarto (2016). Buku Ajar ParasitologiKedokteran (Handbook of Medical Parasitology) (Edisi 2). Jakarta: SagungSeto;

Widoyono (2011). Penyakit Tropis Epidemiologi, Penularan, Pencegahan \& Pemberantasannya. Jakarta: Erlangga;

Hasibuan (2016). Maharani. Uji Fitokimia dan Antibakteri Ekstrak Etanol Daun Ceremai Terhadap Staphylococcus epidermis, Staphylococcus aureus dan Escherichia coli. Medan: USU

Roslizawaty et al., (2013). Aktivitas Antibakterial Ekstrak Etanol dan Rebusan Sarang Semut (Myrmecodia sp.) terhadap Bakteri Escherichia coli. Jurnal Medika Veterinaria. 2013. 7(2):91-93

Dima, Lusi, Fatimawali \& Widya Astuti Lolo (2016). Uji Efektivitas Daun Kelor (moringa oleifera L.) terhadap pertumbuhan Bakteri Escherichia coli dan Ataphylococcus aureus. Pharmachon Jurnal. 2016.5:2302-2493

Tuntun, Maria (2016). Uji Efektivitas Ekstrak Daun Pepaya (Carica papaya L.) Terhadap Pertumbuhan Bakteri Escherichia coli dan Staphylococcus aureus. Jurnal Kesehatan. 2016.7(3):497-502

Afnidar (2014). Fitokimia Dan Uji Aktivitas Antibakteri Ekstrak Kalus Tumbuhan Sernai (Wedelia Biflora (L) Dc.). JESBIO. 2014. 3(4):9-15

Harborne, J.B (1987). Metode Fitokimia: penuntun cara modern menganalisis tumbuhan. Bandung: ITB

Tan, H.T. \& Rahardja, K. (2007). Obat-obat Penting: Khasiat, Penggunaan, dan Efek-efek Sampingnya, edisi keenam. Jakarta: PT. Elex Media Komputindo. 
Robinson, T. (1995). Kandungan Organik Tumbuhan Tinggi, Edisi VI, Hal 191-216, Diterjemahkan oleh Kosasih Padmawinata, ITB, Bandung.

Departemen Kesehatan Republik Indonesia (1995), Farmakope Indonesia, Edisi IV, 606, Departemen Kesehatan Republik Indonesia, Jakarta.

Departemen Kesehatan RI (1979). Farmakope Indonesia Edisi III, 378, 535, 612. Jakarta.

Departemen Kesehatan RI, 2011, Panduan Sosialisasi

Tatalaksana Diare Pada Balita, Jakarta, Kementerian Kesehatan Republik Indonesia Direktorat Jenderal pengendalian Penyakit dan Penyehatan Lingkungan.

Jawetz M \& Adelberg's. (2013). Mikrobiologi Kedokteran. edisi 26. Jakarta: Buku Kedokteran ECG.

Agus et al., (2013). Pengaruh Pemberian Pupuk Hayati (Biofertilizer) Dan Media Tanam Yang Berbeda Pada Pertumbuhan Dan Produktivitas Tanaman Cabai Rawit (Capsicum frutescens L) Di Polybag. Jurnal Sains Dan Teknologi. UNAIR. 